\title{
Effect of 3-substituted 1,4-benzodiazepin-2-ones on maximal normalized rate of bradykinin-induced smooth muscle contraction in the presence of calcium channel blockers
}

\author{
P. A. Virych*, O. V. Shelyuk*, T. A. Kabanova*, O. I. Khalimova**, \\ V. S. Martynyuk*, V. I. Pavlovsky**, S. A. Andronati** \\ *Taras Shevchenko National University of Kyiv, Kyiv, Ukraine \\ **O. V. Bogatsky Physico-Chemical Institute, National Academy of Sciences of Ukraine, Odessa, Ukraine
}

Article info

Received 12.04.2017 Received in revised form 11.05.2017 Accepted 13.05.2017

Taras Shevchenko National University of Kyiv, Glushkova Str., 2, Kyiv, 03022, Ukraine Tel.: +38-096-702-80-44. E-mail: sphaenodon@ukr.net

O. V. Bogatsky Physico-Chemical Institute, National Academy of Sciences of Ukraine, Lustdorfska Doroga, 86, Odessa, 65080, Ukraine Tel.: +38-097-905-92-97. E-mail: victor_pavlovsky@ukr.net
Virych, P. A., Shelyuk, O. V., Kabanova, T. A., Khalimova, O. I., Martynyuk, V. S., Pavlovsky, V. I., \& Andronati, S. A. (2017). Effect of 3-substituted 1,4-benzodiazepin-2-ones on maximal normalized rate of bradykinin-induced smooth muscle contraction in the presence of calcium channel blockers. Regulatory Mechanisms in Biosystems, 8(2), 224-230. doi:10.15421/021735

The development of modern organic chemistry and molecular modeling technologies simplify the search for potential inhibitors of various receptor systems and biological processes. The one of the directions is the development of analgesics of broad spectrum and low toxicity. It is important to search for inhibitors of the kinin-kallikrein system that regulates many functions: inflammation, pain, carcinogenesis, vascular tone, smooth muscle contraction and other. Derivatives of 3-substituted 1,4-benzodiazepine-2-ones have a unique spatial conformation that allows one to simulate $\beta$-structures of bioactive peptides. The functional activity of compounds is determined by properties of their peripheral chemical radicals. We analyzed the effect of 3-substituted 1,4-benzodiazepin-2-ones derivatives on the normalized maximal rate of bradykinin-induced smooth muscle contraction and relaxation of the stomach in the presence of calcium channel blockers: verapamil $(1 \mu \mathrm{M})$, gadolinium $(300 \mu \mathrm{M})$ and 2-aminoethyl diphenylborinate $(0.1 \mu \mathrm{M})$. The levels of bradykinin and 3-arylamino-1,2-dihydro-3H-1,4-benzodiazepine-2-ones in incubation solution were $10^{-6} \mathrm{M}$. Data processing on dynamics of contraction was performed according to the method of Burdyha and Kosterin. Compounds MX-1775 and MX-1925 reduced maximal normalized rate $\left(\mathrm{V}_{\mathrm{n}}\right)$ of bradykinin-induced smooth muscle contraction in the presence of $\mathrm{Gd}^{3+}$ by $21.2 \%$ and $31.0 \%$ respectively. Compound MX-1925 increased $\mathrm{V}_{\mathrm{n}}$ of relaxation by $11.6 \%$. A similar effect is typical for MX-2011, where there is an increase by $34.6 \%$. In the presence of verapamil this compound additionally decreased $V_{n}$ contraction by $20.5 \%$. Substances MX-1775, MX-2004 and MX-1925 restored maximal normalized rate of relaxation to original values of bradykinin-induced contraction. In the presence of 2-aminoethyldiphenylborinate MX-1775 additionally reduced $\mathrm{V}_{\mathrm{n}}$ of contractions by 7.5\%. 3-substituted 1,4-benzodiazepine-2-ones did not change the maximal normalized rate of contraction and relaxation of carbachol- and potentialinduced smooth muscle contraction. Based on the results and previous investigations, the MX-1775 is a potential blocker of kinin $\mathrm{B}_{2}$-receptors. Effects obtained for other compounds require additional research.

Keywords: 3-substituted 1,4-benzodiazepines; bradykinin; kinin-kallikrein system; maximal normalized rate

\section{Вплив 3-заміщених 1,4-бензодіазепін-2-онів на максимальну нормовану швидкість брадикінін-індукованого скорочення гладеньких м'язів за присутності блокаторів кальцісвих каналів}

\author{
П. А. Вірич*, О. В. Шелюк*, Т. А. Кабанова**, О. І. Халімова**, \\ В. С. Мартинюк*, В. І. Павловський**, С. А. Андронаті** \\ *Київський національний університет імені Тараса Шевченка, Київ, Украӥна \\ **Фізико-хімічний інститут імені О. В. Богатського НАН України, Одеса, Україна
}

Пошук антагоністів кінінових рецепторів - перспективне завдання, оскільки кінін-калікреїнова система бере участь у багатьох процесах, що включають регуляцію розвитку запалення, тиску крові, канцерогенезу, больових відчуттів тощо. Похідні 3-заміщених 1,4-бензодіазепін-2-онів володіють унікальною просторовою конформацією, що дозволяє імітувати $\beta$-структури біологічно активних пептидів. Формування особливої структури сполук досягається зміною радикалів, що визначають їх активність. Проаналізовано вплив 
похідних 3-заміщених 1,4-бензодіазепін-2-онів на максимальну нормовану швидкість $\left(\mathrm{V}_{\mathrm{n}}\right)$ брадикінін-індукованого скорочення та розслаблення гладеньких м'язів за присутності верапамілу (1 мкM), іонів $\mathrm{Gd}^{3+}$ (300 мкМ) та 2-аміноетилдифенілборіату (0,1 мкМ). Речовини MX-1775 та MX-1925 сприяють додатковому зниженню максимальної швидкості скорочення на 21,2 \% та $31,0 \%$ відповідно за наявності в розчині $\mathrm{Gd}^{3+}$. Сполука MX-1925 здатна збільшувати $\mathrm{V}_{\mathrm{n}}$ розслаблення на 11,6\%. Подібний ефект характерний для МХ-2011, де спостерігається зростання $\mathrm{V}_{\mathrm{n}}$ на $34,6 \%$. За присутності верапамілу ця сполука додатково інгібує $\mathrm{V}_{\mathrm{n}}$ скорочення на 20,5\%. Усі вибрані речовини, окрім MX-2011, відновлюють $\mathrm{V}_{\mathrm{n}}$ розслаблення до початкових значень брадикінін-індукованих скорочень. На фоні присутності 2-аміноетилдифенілборіату MX-1775 додатково знижує $\mathrm{V}_{\mathrm{n}}$ скорочення на 7,5\%. Проведені дослідження зі впливу 3-заміщених 1,4-бензодіазепін-2-онів на потенціал- і карбахолін-індуковане скорочення гладеньких м'язів шлунка щурів не виявили статистично достовірних змін максимальної нормованої швидкості скорочення та розслаблення. Виходячи 3 попередніх досліджень і отриманих

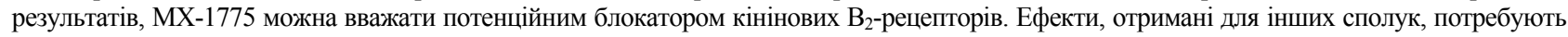
додаткових досліджень.

Ключові слова: 3-заміщені 1,4-бензодіазепін-2-они; брадикінін; кінін-калікреїнова система; максимальна нормована швидкість

\section{Вступ}

Біль - складне багатовимірне сенсорно-перцептивне явище, що важко піддається визначенню. Поняття болю трактується як неприємне сенсорне та емоційне переживання, пов'язане 3 фактичним або потенційним пошкодженням тканин. Як відомо, за пошкодження нервових волокон виникає спонтанна електронна збудливість і надчутливість, що виявляється зміною експресії нейромедіаторів, факторів росту, рецепторів і нейроактивних молекул первинних аферентних нейронів (Ваron et al., 2010). Така периферична сенсибілізація посилює ноцицепцію, що спричиняє больову гіперчутливість (Gierthmuhlen et al., 2014; Puretić and Demarin, 2012), у тому числі до виникнення спонтанного болю та гіпералгезивного підвищення температури. Важлива умова боротьби з больовими відчуттями - з'ясування механізмів їх виникнення. Насамперед це стосується периферичних складових, не пов'язаних із нервовою системою. Як вважається, одна 3 них - кінін-калікреїнова система. Вона складається з неактивних попередників - кініногенів, калікреїнів плазми крові та тканин, а також специфічних активаторів цих субстратів, що продукують вазоактивні пептиди - брадикінін і калідин. За дії брадикініну відбувається ініціація клітинної відповіді відбувається через низку поверхневих рецепторів клітини. Брадикінінові рецептори спряжені 3 G-білками, мають 7 трансмембранних доменів (7TM). Існує два їх підтипи ( $\mathrm{B}_{1}$ та $\left.\mathrm{B}_{2}\right)$, що підтверджено з використанням специфічних високоафінних непептидних антагоністів, радіолігандне зв'язування та клонування самих рецепторів із подальшою їх експресією. Різниця в афінності антагоністів рецепторів $\mathrm{B}_{2}$, які включають [DPhe7]-брадикінін, D-Arg-[Hyp3, Thi5, D-Tic7, Oic8]-брадикінін та непептидний WIN64338, дозволила визначити деякі гомологи даного рецептора, у тому числі трахеальний $\mathrm{B}_{3}$ (Hall, 1997).

Рецептори $\mathrm{B}_{1}$ та $\mathrm{B}_{2}$ - важливі медіатори серцево-судинного гомеостазу, запалення та ноцицепції. У той час як $\mathrm{B}_{2}$ конститутивно експресується у багатьох тканинах, синтез $\mathrm{B}_{1}$ індукується лише за прозапальних умов. Ранні дослідження впливу кінінів на травну систему, особливо на гладенькі м'язи, проведено в 19601970-і роки. Показано, що очищений м'язовий шар тонкого кишечника чутливий до наднизьких доз кінінів $(0,1$ нг/мл) і відповідає на них скороченням. Також додавання брадикініну сприяє збільшенню цитозольного кальцію міоцитів клубової кишки.

Дослідження скоротливої активності шлунка щурів у відповідь на аплікацію брадикініну та його аналогів виявило, що скорочення має двофазний характер: перша фаза скорочення 3 незначною релаксацією та наступна - повільного скорочення 3 остаточним розслабленням (Calixto and Medeiros, 1992). Присутність кінінових рецепторів різних типів у шлунково-кишковому тракті дозволяє використовувати їх як моделі дослідження модифікаторів активності кінін-калікреїнової системи, у тому числі інгібіторів або активаторів $\mathrm{B}_{1}$ та $\mathrm{B}_{2}$ брадикінінових рецепторів. Підтвердженням такого припущення стали паралельні радіолігандні дослідження зв'язування агоністів і антагоністів брадикінінових рецепторів (Meini et al., 2007).

Вивчення популяції кінінових рецепторів у інтерстиціальних клітинах Кахаля показало відсутність рецепторів $\mathrm{B}_{1}$ i присутність $\mathrm{B}_{2}$ (Choi et al., 2006). Ці рецептори опосередковують інгібування перистальтичної активності клубової кишки морської свинки (Chan and Rudd, 2006). Природні речовини деяких рослин після незначної хімічної модифікації структури можуть стати перспективними модифікаторами активності кінін-калікреїнової системи, що доведено експериментально на скоротливій здатності шлунка мишей (Alves et al., 2015). Під час розвитку запальних процесів у шлунково-кишковому тракті відбувається продукування активних кінінів, що діють на конститутивно присутні $\mathrm{B}_{2}$ рецептори, які швидко десенситизуються та індукують вивільнення запальних цитокінів $\mathrm{i}$ експресію рецептора $\mathrm{B}_{1}$, резистентного до сенситизації.

Тканинні калікреїни кишечника здатні гідролізувати фактори росту та інші пептиди, у той час як кініни відповідають за проникність капілярів, розвиток больових відчуттів, синтез цитокінів і молекул адгезії нейтрофілів. Вивільнення калікреїнів відбувається в келихоподібних клітинах тонкого кишечника під час розвитку запальних процесів. Використання блокаторів $\mathrm{B}_{2}$ рецепторів дозволяє зменшити перистальтику кишечника, у той час як інгібування $\mathrm{B}_{1}$ рецепторів сприяє зниженню запалення. Активація обох рецепорів спричиняє розвиток діареї (Stadnicki, 2011). Схожі дослідження проведено для вивчення ролі $\mathrm{B}_{1}$ та $\mathrm{B}_{2}$ кінінових рецепторів у розвитку колітів (Marcon et al., 2013).

Взаємодія брадикініну зі специфічним поверхневим рецептором клітини викликає зміни рівнів цитоплазматичного кальцію із залученням різних систем, таких як фосфоліпаза С, простагландини, протеїнкінази та фосфоліпаза $\mathrm{A}_{2}$. Розвиток сучасної органічної хімії дозволяє синтезувати антагоністи непептидної природи, що потенційно можуть застосовуватись як блокатори активності кінін-калікреїнової системи кишечника (Kam Ro et al., 2005; Fattori et al., 2007). Для створення речовин, здатних взаємодіяти з рецепторним апаратом кінін-калікреїнової системи, використовують бензодіазепінове ядро, здатне набувати структури $\beta$-згину біологічно активних пептидів. Приклад такої речовини - антагоніст $\mathrm{B}_{2}$ рецепторів $\mathrm{HOE} 140$, який лежить в основі розробки непептидних $\mathrm{B}_{2}$ антагоністів (Dziadulewicz et al., 1999). Тому пошук непептидних модифікаторів активності кінінових рецепторів на основі бензодіазепінового ядра - перспективний напрям досліджень фармакологічно активних сполук даного класу. Їх застосування дозволить боротись із запальними процесами, регулювати функціональний стан серцево-судинної системи, долати больові відчуття тощо.

Науковий колектив Фізико-хімічного інституту НАН України імені О. В. Богатського розробив новий клас перспективних сполук на основі 3-заміщених 1,4-бензодіазепінів, які володіють анальгетичною дією. Експериментальні дані демонструють здатність деяких похідних бенздіазепінів проявляти чітку антигіперальгезивну активність відносно запального та невропатичного болю на тваринних моделях. Деякі похідні бензодіазепінів можуть викликати глибоку анальгезію у тварин (Andronati et al., 2009).

Попередні дослідження активності спектра похідних 3-заміщених 1,4-бензодіазепін-2-онів дозволили ідентифікувати декілька сполук, здатних виявляти біологічну активність та змінювати механо-кінетичні параметри брадикінін-індукованого скорочення гладеньких м'язів (Virych et al., 2017). Шляхи трансдукції сигналу брадикінінових рецепторів включають також 
активацію кальцієвих каналів різного типу, які забезпечують зростання концентрації іона в цитоплазмі клітини та ініціацію скорочення. Застосування верапамілу дозволяє заблокувати потенціалчутливі кальцієві канали T- i L-типів, у результаті чого змінюється швидкість і амплітуда викликаного скорочення. Іони гадолінію здатні конкурувати за селективний фільтр, тому також спричиняють зміни механо-кінетичних параметрів скорочення гладеньких м'язів. До одного з посередників індукції скоротливої відповіді міоцитів належать рецептори інозитол-1,4,5-трифосфату, локалізовані на ендоплазматичному ретикулумі. Їх активація спричиняє викидання кальцію з внутрішньоклітинних депо, тому вони відіграють важливу роль у сигнальному каскаді кінінових рецепторів.

Беручи за основу модель брадикінін-індукованого скорочення гладеньких м'язів шлунка щурів, за мету цього дослідження обрали перевірку активності похідних 3-заміщених 1,4-бензодіазепін-2-онів за присутності блокаторів кальцієвих каналів (верапамілу, іонів гадолінію та 2-аміноетилдифенілборіату), а також визначення їх впливу на механокінетичні параметри потенціал- і карбахолін-індукованих скорочень гладеньких м'язів.

\section{Матеріал і методи досліджень}

Ізометричні дослідження скоротливої активності гладеньких м'язів проведено під час інкубування в нормальному розчині Кребса такого складу (мМ): $120,4 \mathrm{NaCl}, 5,9 \mathrm{KCl}, 15,5$ $\mathrm{NaHCO}_{3}, 1,2 \mathrm{NaH}_{2} \mathrm{PO}_{4}, 1,2 \mathrm{MgCl}_{2}, 2,5 \mathrm{CaCl}_{2}, 11,5$ глюкоза; $\mathrm{pH}$ розчину становив 7,4. Відбирали щурів-самців масою 240-260 г, утримували їх в умовах віварію ННЦ «Нститут біології та медицини». Усі маніпуляції з тваринами проводили згідно з Міжнародною конвенцією про роботу з тваринами та Законом України «Про захист тварин від жорстокого поводження». Після швидкої декапітації вилучали шлунок. Очищений м'язовий шар антральної частини шлунка нарізали на смужки розміром 1,5 × 20 мм. Інкубували в камері зі швидкістю потоку 1,5 мл/хв та сталою температурою $+37^{\circ} \mathrm{C}$. Препарату надавали пасивний натяг силою $10 \mathrm{mH} \mathrm{і} \mathrm{витримували} \mathrm{протягом} \mathrm{однієї} \mathrm{години} \mathrm{до}$ появи спонтанних скорочень або сталих механо-кінетичних параметрів у відповідь на стимуляцію гіперкалієвим розчином (80 мМ). Останній готували на основі розчину Кребса шляхом заміни $\mathrm{Na}^{+}$на еквівалентну кількість $\mathrm{K}^{+}$.

Реєстрували за допомогою модуля збирання даних $\mathrm{m}$ DAQ12 (Holit Data Systems Ltd., Україна) та програмного забезпечення PowerGraph Professional 3.3.

Необхідну концентрацію брадикініну $\left(10^{-6} \mathrm{M}\right)$ для стимуляції скорочень створювали під час додавання аліквоти маточного розчину (1 мМ) в інкубаційну камеру. Дослідження впливу похідних 3-заміщених 1,4-бензодіазепін-2-онів проводили за конститутивної їх присутності у розчині Кребса. Кінцева концентрація становила $10^{-6}$ М. Дію досліджуваних речовин вивчали за однаковим протоколом експерименту, сполуки вносили в розчин Кребса за 30 хв до реєстрації механічної активності препаратів. Перелік використаних речовин та їх хімічну структуру наведено в таблиці 1.

Використання блокаторів кальцієвих каналів дозволяє вимкнути окремі ланки ланцюга трансдукції сигналу від брадикінінових рецепторів та виявити можливий синергізм чи антагонізм їх дії з 3-заміщеними 1,4-бензодіазепін-2-онами. Іони гадолінію здатні блокувати селективний фільтр кальцієвих каналів, перешкоджаючи тим самим руху $\mathrm{Ca}^{2+}$ (Malasics et al., 2010). Верапаміл - класичний блокатор потенціал-активованих кальцієвих каналів T- i L-типів (Bergson et al., 2011). Кінцева концентрація $\mathrm{Gd}^{3+}$ у розчині інкубації становила 300 мкМ, верапамілу - 1 мкМ. Відповідний блокатор постійно присутній в омивальному розчині Кребса. 2-аміноетилдифенілборіат застосовують для блокування виходу кальцію 3 внутрішньоклітинних депо. Сполука виступає антагоністом рецепторів інозитол1,4,5-трифосфату та TRP-каналів (Bon and Beech 2013; Bencze et al., 2015; Seidlmayer et al., 2016). У дослідженнях використали концентрацію 100 нМ для запобігання виходу кальцію 3 саркоплазматичного ретикулуму та активації ТRP-каналів.
Як нульові значення обрано показники гладеньком'язового скорочення за присутності в розчині Кребса 1\% ДМСО, що пов'язано з низькою розчинністю 3-заміщених 1,4-бензодіазепін-2-онів у воді.

\section{Таблиця 1}

Хімічна структура похідних 3-заміщених 1,4-бензодіазепін-2-онів

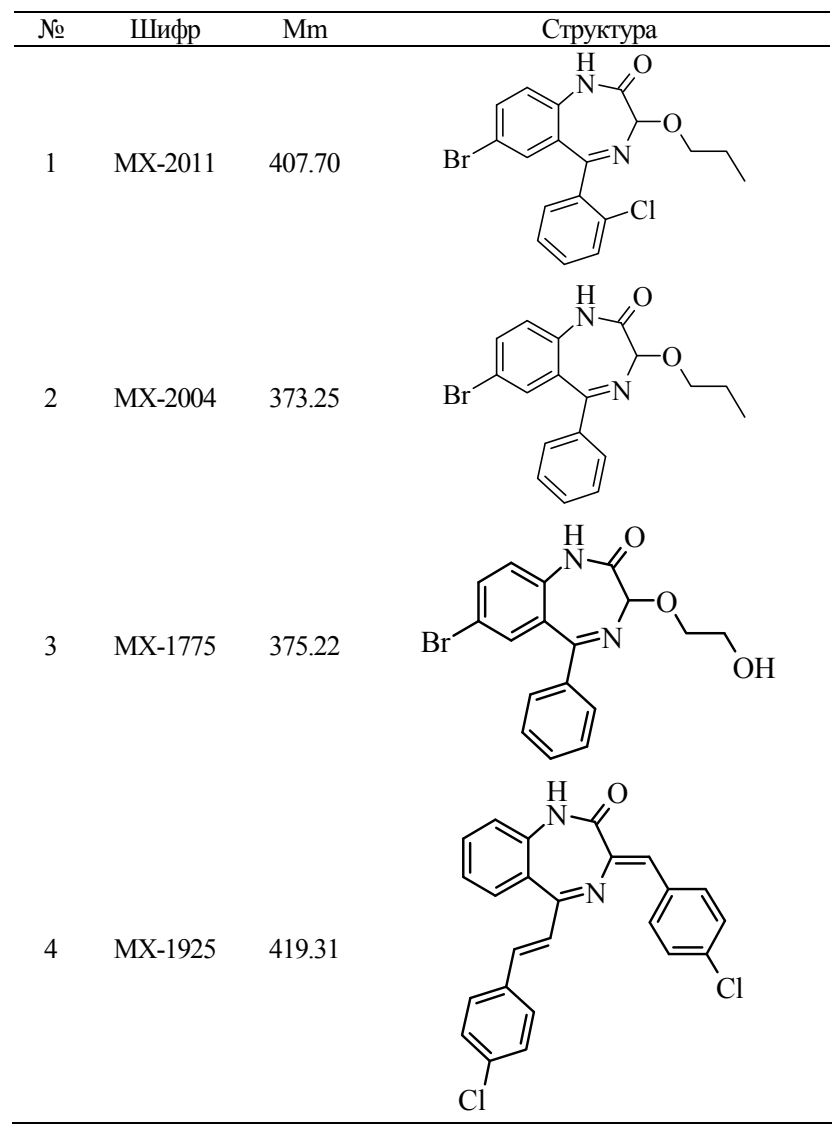

Афінність дії 3-заміщених 1,4-бензодіазепін-2-онів на брадикінін-індуковане скорочення передбачає відсутність впливу на інші системи регуляції гладеньком'язового скорочення, насамперед потенціал- і карбахолін-індуковане. Для перевірки цієї гіпотези використали $80 \mathrm{mM}$ гіперкалієвий розчин і 10 мкМ розчин карбахоліну. Кінцева концентрація 3-заміщених 1,4-бенздіазепін-2-онів становила $10^{-6} \mathrm{M}$. Для оцінювання використано дві послідовні стимуляції: перша - у звичайному розчині Кребca, друга - на фоні додавання аліквоти досліджуваної речовини (кінцева концентрація $10^{-6} \mathrm{M}$ ).

Аналіз механокінетичних параметрів скорочення гладеньких м'язів проводили методом Burdyga and Kosterin (1991) iз розрахунком максимальної нормованої швидкості скорочення та розслаблення. Статистичну обробку даних проводили за допомогою пакетів програм Statistica 8.0 та OriginLab 8.0. Peзультати перевіряли на нормальність розподілу за допомогою тесту Шапіро - Вілка. Розрахунок різниці між контрольними та дослідними значеннями проводили за допомогою ANOVA (Шеффе-тест) для незалежних вибірок. Якщо дані не відповідали закону нормального розподілу, порівняння незалежних вибірок проводили за критерієм Краскела - Уолліса. Різницю між вибірками вважали достовірною за $\mathrm{P}<0,05$.

\section{Результати}

Ефективність визначали шляхом розрахунку різниці між брадикінін-індукованими скороченнями за присутності та відсутності відповідних інгібіторів. Нульовим показником виступають значення брадикінін-індукованого скорочення за відсутності блокаторів (рис. 1,2 ). Присутність у розчині $\mathrm{Gd}^{3+}$ у кіль- 
кості 300 мкМ забезпечує зниження максимальної нормованої швидкості скорочення на $23,1 \%$, що вибрано контролем. Відносно цього значення здійснювали порівняння дії дослідних сполук. Присутність в інкубаційному розчині MX-1775 додатково знижує $\mathrm{V}_{\mathrm{n}}$ скорочення на 21,2\%, MX-1925 - на 31,0\%. Статистично достовірних змін не виявлено для МХ-2004 та MX-2011 (рис. 1А). Отриманий ефект можливий внаслідок двох процесів: здатності речовин взаємодіяти $3 \mathrm{~B}_{2}$-рецептором або мати додаткові мішені, залучені до ланцюга трансдукції сигналу. Варто зазначити, що попередньо ці сполуки виявляли схожість дії 3 конкурентним інгібітором $\mathrm{B}_{2}$-рецепторів - des-Arg9-брадикінін ацетатом, сприяючи зростанню $\mathrm{V}_{\mathrm{n}}$ скорочення у міру збільшення концентрації брадикініну в діапазоні $10^{-10}-10^{-6} \mathrm{M}$.

Максимальна нормована швидкість розслаблення за присутності $\mathrm{Gd}^{3+}$ зростає на 7,4\% (рис. 1Б). Статистично достовірних відхилень від цього показника для MX-1775 та MX-2004 не спостерігали. Показник зростає відносно контролю на 11,6\% за присутності MX-1925 та на 34,6\% - MX-2011 (рис. 1Б). Зміни цього показника вказують на тривалість підтримання високого рівня іонів кальцію в цитоплазмі клітин і ефективності роботи кальцієвих помп.

Присутність у розчині верапамілу забезпечує зниження $\mathrm{V}_{\mathrm{n}}$ брадикінін-індукованого скорочення на 49,3\%. Для MX-1775, MX-2004 та МX-1925 статистично достовірні відхилення від

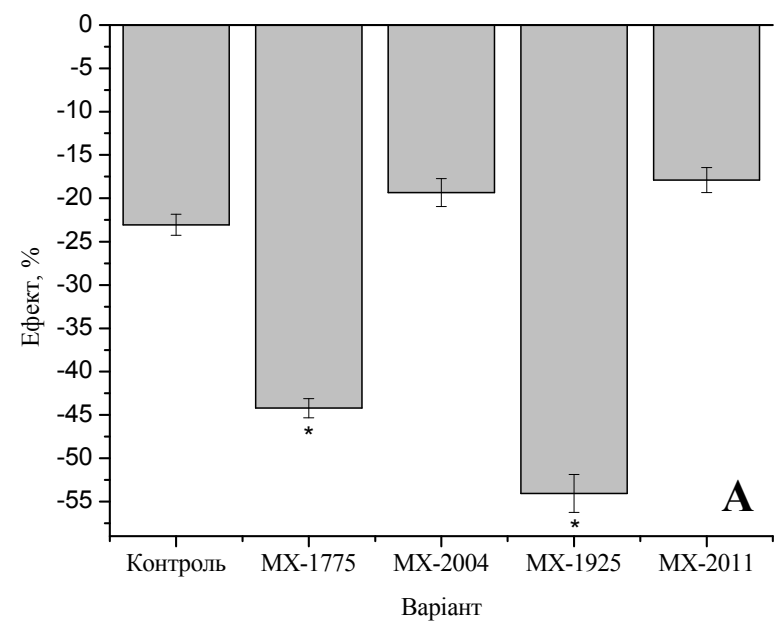

цього показника відсутні. МХ-2011 виявляє додаткове інгібування на 20,5\% (рис. 2А).

Максимальна нормована швидкість розслаблення за таких умов для МX-1775, MX-2004 та MX-1925 перебуває в межах нульового значення, тобто показників брадикінін-індукованого скорочення за відсутності модифікаторів. МХ-2011 сприяє зниженню показника на 9,9\% відносно контролю. Отже, ми спостерігаємо відновлення початкових показників брадикінін-індукованого скорочення за присутності 3-заміщених 1,4-бензодіазепін-2-онів.

Використання 2-аміноетилдифенілборіату як інгібітора TRPканалів і рецепторів IP3 дозволяє виключити одну з останніх ланок трансдукції сигналу брадикінінових рецепторів: взаємодії вивільненого фосфоліпазою С інозитол-1,4,5-трифосфату 3 відповідними рецепторами саркоплазматичного ретикулуму, тим самим заблокувавши вихід $\mathrm{Ca}^{2+}$ iз внутрішьоклітинних депо. На фоні цього перевірили вплив досліджуваних сполук на максимальну нормовану швидкість скорочення та розслаблення (рис. 3). Ефект повністю відсутній для $\mathrm{V}_{\mathrm{n}}$ розслаблення вибраних сполук на фоні зменшення показника за дії 2-аміноетилдифенілборіату на 9,4\% (рис. 3Б). $V_{n}$ скорочення за таких умов також не піддається змінам для МХ-2011, MX-2004, MX-1925 відносно контрольного показника 44,5\%. Сполука МХ-1775 дозволяє додатково знизити параметр на 7,5\% (рис. $3 \mathrm{~A}$ ).

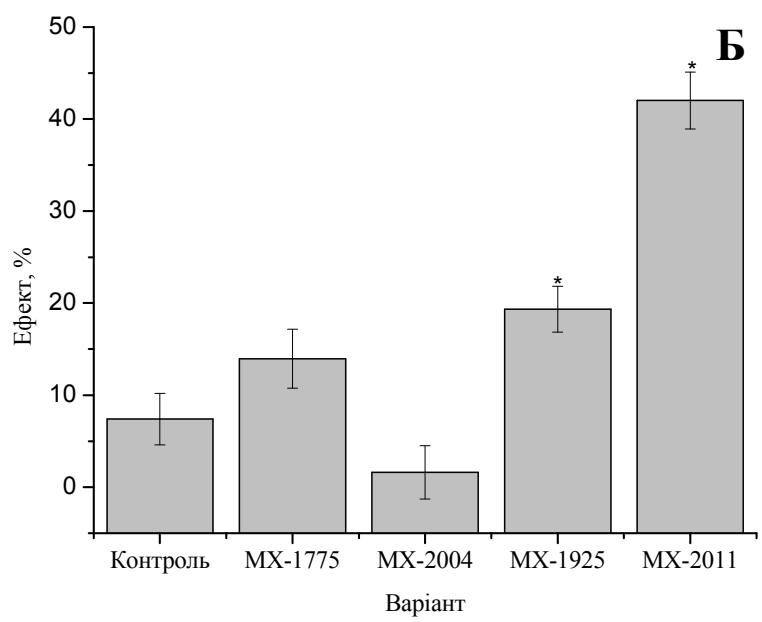

Рис. 1. Вплив 3-заміщених 1,4-бензодіазепін-2-онів на максимальну нормовану швидкість скорочення $(A)$ та розслаблення $(Б)$ за присутності $\mathrm{Gd}^{3+}(300 \mathrm{M \kappa M}):\left\langle 0 »-\mathrm{V}_{\mathrm{n}}\right.$ брадикінін-індукованого скорочення, контроль - за присутності $\mathrm{Gd}^{3+} ; \mathrm{M} \pm \mathrm{m}, \mathrm{n}=10,{ }^{*}-\mathrm{P}<0,05$
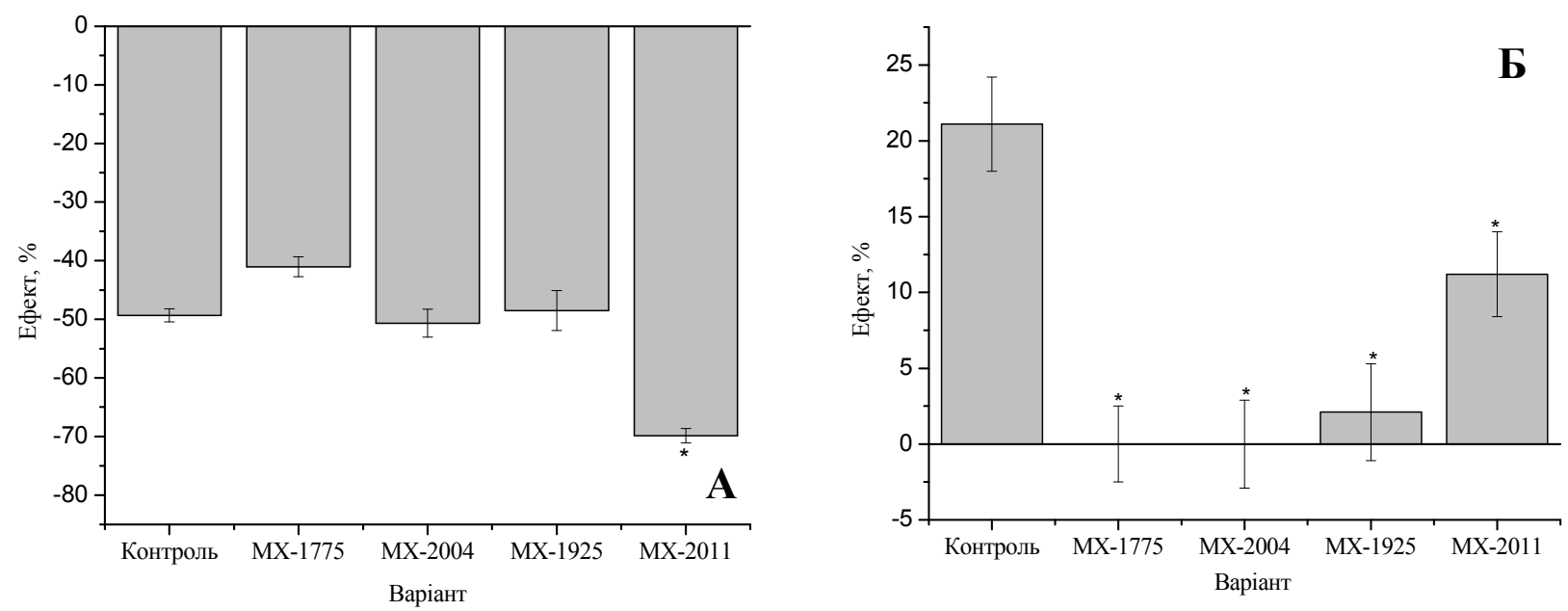

Рис. 2. Вплив 3-заміщених 1,4-бензодіазепін-2-онів на максимальну нормовану швидкість скорочення ( $A$ ) та розслаблення $(Б)$ за присутності верапамілу (1 мкM): «0» - $\mathrm{V}_{\mathrm{n}}$ брадикінін-індукованого скорочення, контроль - за присутності верепамілу; $\mathrm{M} \pm \mathrm{m}, \mathrm{n}=10,{ }^{*}-\mathrm{P}<0,05$

Дослідження впливу 3-заміщених 1,4-бензодіазепін-2-онів на потенціал-індуковане скорочення не виявили статистично достовірних змін максимальної нормованої швидкості скорочення та розслаблення (рис. 4). Можна припустити, що вибрані сполуки не здатні взаємодіяти з потенціал-чутливими канала- ми мембрани, залученими до активації скоротливого процесу. Аналогічні дослідження проведено для карбахолін-індукованого скорочення. Ацетилхолін - один з основних нейромедіаторів контролю перистальтики шлунково-кишкового тракту 3 боку нервової системи. Порушення нормального функціону- 
вання однієї з ланок шляху, що залучений до цього процесу, спричинює важкі патології. Перевірка взаємодії досліджуваних сполук із холінергічною системою контролю функціонування гладеньких м'язів кишечника стає важливим етапом тестування.

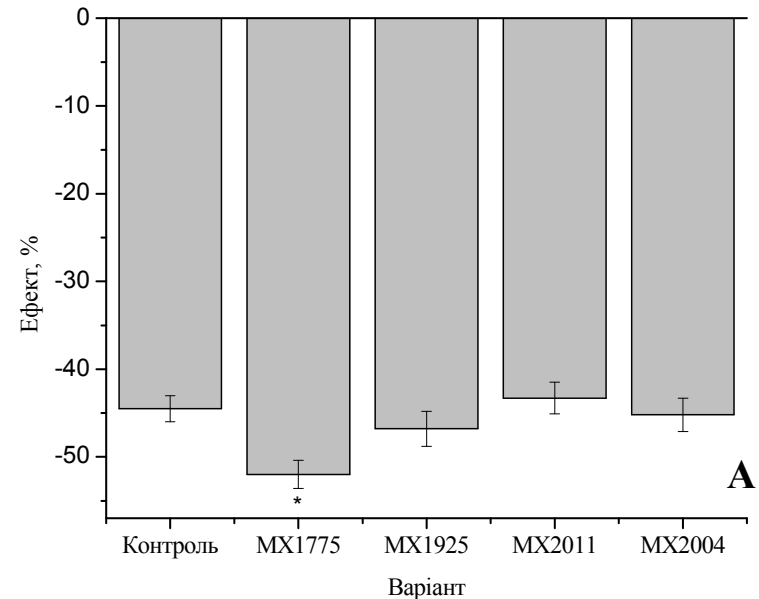

Вибрані 3-заміщені 1,4-бензодіазепін-2-они статистично достовірно не змінюють максимальної нормованої швидкості скорочення та розслаблення карбахолін-індукованого скорочення (рис. 5).

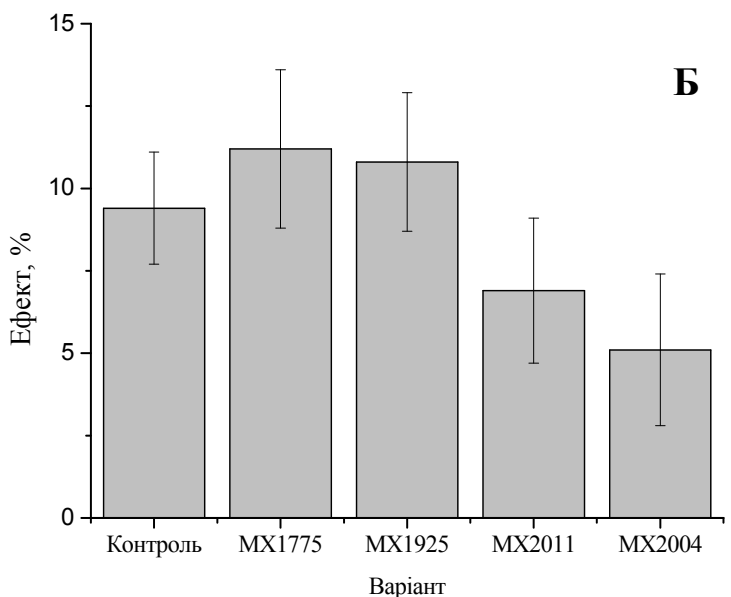

Рис. 3. Вплив 3-заміщених 1,4-бензодіазепін-2-онів на максимальну нормовану швидкість скорочення $(A)$ та розслаблення $(Б)$ за присутності 2-аміноетилдифенілборіат (0,1 мкM): «0»- $\mathrm{V}_{\mathrm{n}}$ брадикінін-індукованого скорочення, контроль - за присутності 2-аміноетилдифенілборіату; $\mathrm{M} \pm \mathrm{m}, \mathrm{n}=10, *-\mathrm{P}<0,05$
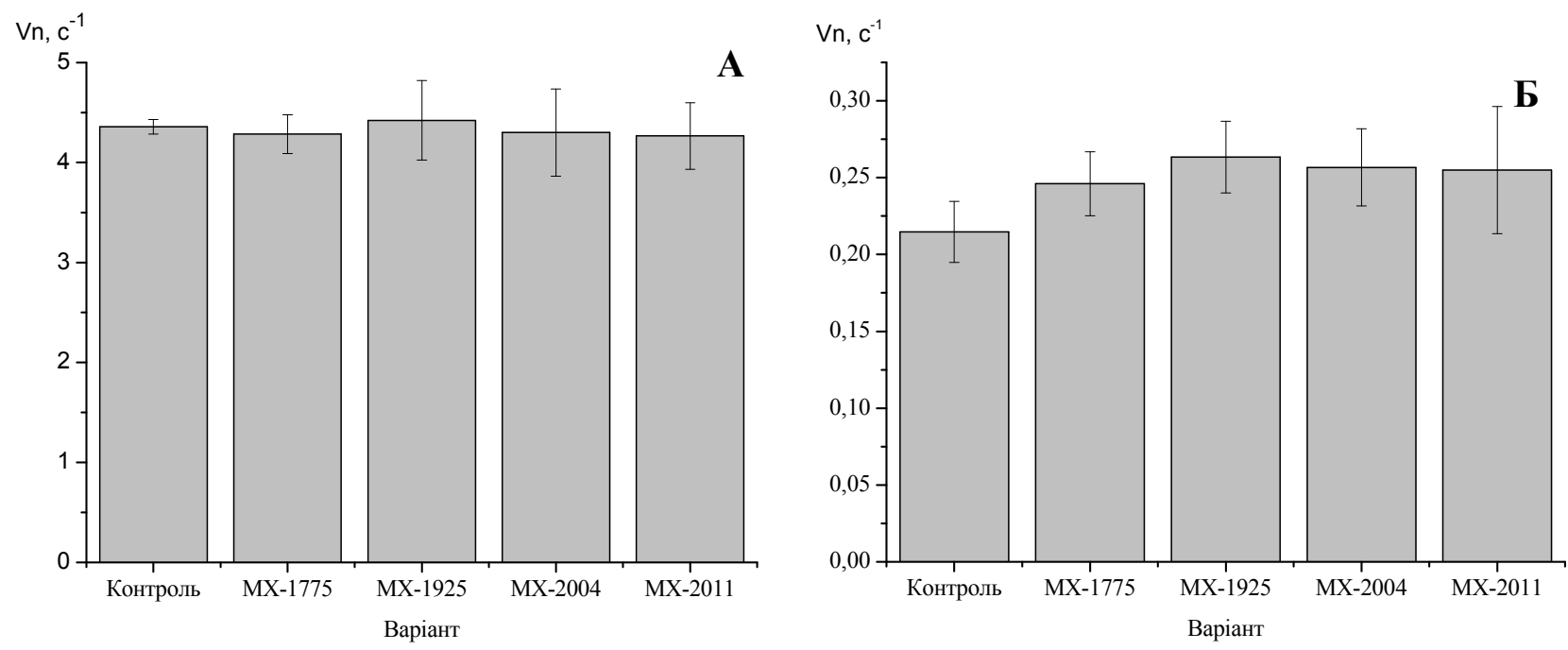

Рис. 4. Вплив 3-заміщених 1,4-бензодіазепін-2-онів на максимальну нормовану швидкість потенціал-індукованого скорочення (A) та розслаблення $($ Б) $: \mathrm{M} \pm \mathrm{m}, \mathrm{n}=10, *-\mathrm{P}<0,05$
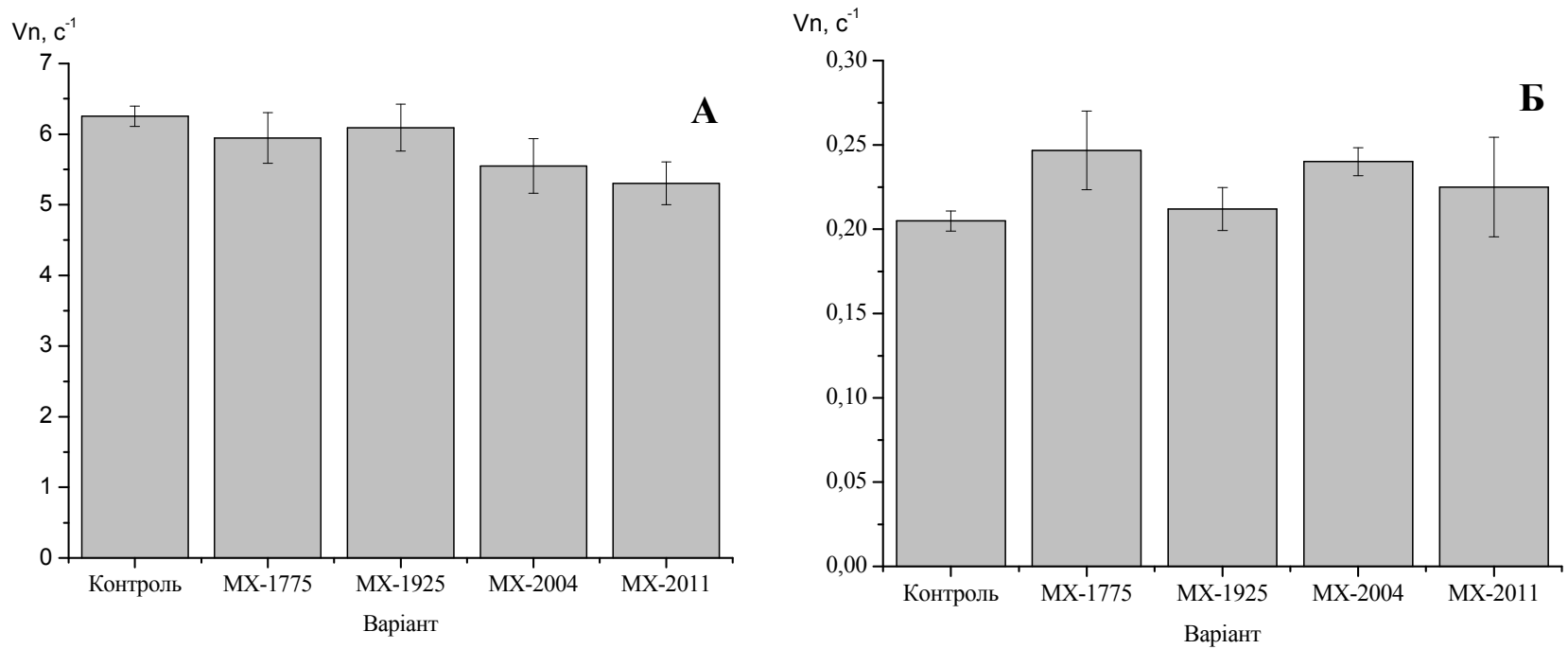

Рис. 5. Вплив 3-заміщених 1,4-бензодіазепін-2-онів на максимальну нормовану швидкість карбахолін-індукованого скорочення ( $A$ ) та розслаблення $\left(\right.$ Б): $\mathrm{M} \pm \mathrm{m}, \mathrm{n}=10,{ }^{*}-\mathrm{P}<0,05$ 


\section{Обговорення}

Сполуки на основі бензодіазепінів являють широкий спектр речовин, які впливають на різні біохімічні процеси. Забезпечується це особливостями просторової структури, яка формує аналог $\beta$-згину біологічно активних пептидів. За рахунок хімічної модифікації основного ядра молекули вдається досягти необхідних характеристик розчинності та стійкості отриманої структури до дії тканинних оксидаз та естераз. Але метаболізм має відбуватися досить швидко, для уникнення накопичення та створення токсичного ефекту. Процес здійснюється у три стадії: гідроксилювання, деметилювання та глюуронізація (Persona et al., 2015). Реакції біотрансформації, в яких такі похідні 1,4-бензодіазепінів як діазепам, нордіазепам (нордазепам) i темазепам виводяться 3 організму у вигляді оксазепаму або оксазепам глюкоуроніду належать до найвідоміших. Також за наркотичного сп'яніння або передозування у сечі найчастіше знаходять цей метаболіт (Persona et al., 2015).

Класично 3-заміщені 1,4-бензодіазепіни використовуються для модифікації активності GABA-рецепторів, але з часом з'явились повідомлення про їх застосування як блокаторів інших типів рецепторів, біохімічних процесів і протипаразитарних засобів. Периферичні бензодіазепінові рецептори беруть участь у захисті клітин від кисневих радикалів. Використання агоністів цих рецепторів, наприклад Ro5-4864, дозволяє активувати їх та знизити таким чином негативний вплив вільних радикалів на серцевий м'яз (Jaiswal et al., 2010).

Останні дослідження фармакологічних особливостей похідних бензодіазепінів виявили здатність селективно інгібувати лізиндезацетилазу людини. Біологічно активні сполуки ефективно знижували активність ізоформ ензиму 1, 3 та 6 за наномолярних кількостей, і мікромолярних для ізоформи 8 (Reddy et al., 2017).

За останні два десятиліття похідні бензодіазепінів застосовують для боротьби із запальними процесами тканин. Основні їх мішені представлені кініновими рецепторами двох класів $\mathrm{B}_{1}$ та $\mathrm{B}_{2}$. Важливо розуміти їх взаємозв'язок: перший тип - індуковані кінінові рецептори, що експресуються у відповідь на пошкодження тканини, активацію рецепторів $\mathrm{B}_{2}$, продукцію запальних цитокінів та інших прозапальних медіаторів; рецептори $\mathrm{B}_{2}$ конститутивно присутні у більшості тканин організму, за активації відбувається їх швидка десенситизація та поступова заміна на тип $\mathrm{B}_{1}$. Такий процес відбувається протягом 56 годин (Zhang et al., 2015; Prado et al., 2002).

Досліджені нами сполуки мають структуру класичних аналгетичних засобів: гідрофобне ядро та гідрофільні периферичні радикали. Властивості молекули дозволяють їй проникати через мембрану та взаємодіяти 3 мішенями як у самій мембрані, так і всередині клітини.

Попередньо проведені дослідження активності сполук MX-2011, MX-2004, МХ-1775 та МХ-1925 виявили їх інгібувальну дію на брадикінін-індуковане скорочення. Ми припустили, що вони здатні змінювати активність кінінових рецепторів, та використали низку інгібіторів, що вимикали окремі ланки ланцюга трансдукції. Попередньо ідентифіковано речовину MX-1775, яка виявляла активність, схожу до конкурентного інгібітора рецепторів $B_{2}$ - des-Arg9-брадикінін ацетату за некумулятивного збільшення концентрації брадикініну як активатора скорочення, але всі сполуки здатні знижувати $\mathrm{V}_{\mathrm{n}}$ скорочення. Використання блокаторів різних ланок трансдукції сигналу від рецепторів дозволяє виявити сполуки, які взаємодіють із рецептором або ланцюгом передачі сигналу. Причому слабкі взаємодії не сприятимуть додатковим змінам $\mathrm{V}_{\mathrm{n}}$, а сполуки, які виявлятимуть спрямовану активність за присутності різних блокаторів, стають потенційними кандидатами на роль антагоністів рецепторів $\mathrm{B}_{2}$. Для речовини MX-1775 визначено таку поведінку, що виявляється у додатковому зниженні $\mathrm{V}_{\mathrm{n}}$ скорочення за присутності іонів $\mathrm{Gd}^{3+}$ та 2-аміноетилдифенілборіату, а також схожості до des-Arg9-брадикінін ацетату. Додаткове зниження максимальної нормованої швидкості скорочення на
$31,2 \%$ за присутності іонів $\mathrm{Gd}^{3+}$ виявлено для MX-1925, але за додавання інших блокаторів ефект зникає. Ми припускаємо слабкі взаємодії цієї сполуки із шляхом трансдукції сигналу від кінінових рецепторів. Також МX-1925 володіє високою загальною анальгетичною активністю, яку попередньо визначали за допомогою методу «оцтовокислих кущів».

Для пошуку інгібіторів важливо враховувати їх дію на інші шляхи активації скорочення гладеньких м'язів. Проведені нами дослідження впливу 3-заміщених 1,4-бензодіазепін-2-онів на потенціал- і карбахолін-індуковані скорочення гладеньких м'язів шлунка щурів не виявили змін максимальної нормованої швидкості скорочення та розслаблення. Можна припустити, що сполуки не впливають на потенціал-чутливі канали мембрани міоцитів і адренергічну регуляцію скорочення. Ці результати важливі для розроблення інгібіторів кінінових рецепторів і анальгетичних засобів комплексної дії.

\section{Висновки}

Дослідження дії 3-заміщених 1,4-бензодіазепін-2-онів на брадикінін-індуковане скорочення гладеньких м'язів за присутності іонів гадолінію дозволило ідентифікувати сполуки МX1775 та MX-1925, які додатково знижують $\mathrm{V}_{\mathrm{n}}$ скорочення на 21,2\% і 31,0\%, відповідно. При цьому МХ-1925 здатна збільшувати $\mathrm{V}_{\mathrm{n}}$ розслаблення на $11,6 \%$. Подібний ефект характерний для MX-2011, де спостерігається зростання $\mathrm{V}_{\mathrm{n}}$ на $34,6 \%$. За присутності верапамілу ця сполука додатково інгібує $\mathrm{V}_{\mathrm{n}}$ скорочення на 20,5\%. Усі обрані речовини, крім MX-2011, здатні відновлювати $\mathrm{V}_{\mathrm{n}}$ розслаблення до початкових значень брадикінін-індукованих скорочень. За присутності 2-аміноетилдифенілборіату сполука MX-1775 додатково знижує $\mathrm{V}_{\mathrm{n}}$ скорочення на 7,5\%. Не виявлено впливу досліджуваних 3-заміщених 1,4-бензодіазепін-2-онів на потенціал- і карбахолініндуковане скорочення. Виходячи 3 попередніх досліджень і отриманих результатів, MX-1775 - потенційний блокатор кінінових рецепторів $\mathrm{B}_{2}$. Ефекти, отримані для інших сполук, потребують подальших досліджень.

\section{References}

Alves, F., Oliva, M., \& Miranda, A. (2015). Conformational and biological properties of Bauhinia bauhinioides kallikrein inhibitor fragments with bradykinin-like activities. Journal of Peptide Science, 21(6), 495-500.

Baron, R., Binder, A., \& Wasner, G. (2010). Neuropathic pain: Diagnosis, pathophysiological mechanisms, and treatment. The Lancet Neurology, 9(8), 807-819.

Bencze, M., Behuliak, M., Vavř́nová, A., \& Zicha, J. (2015). Broad-range TRP channel inhibitors (2-APB, flufenamic acid, SKF-96365) affect differently contraction of resistance and conduit femoral arteries of rat. European Journal of Pharmacology, 765(15), 533-540.

Bergson, P., Lipkind, G., Lee, S., Duban, M., \& Hanck, D. (2011). Verapamil block of T-type calcium channels. Molecular Pharmacology, 79(3), 411-419.

Bon, R., \& Beech, D. (2013). In pursuit of small molecule chemistry for calcium-permeable non-selective TRPC channels - mirage or pot of gold? British Journal of Pharmacology, 170(3), 459-474.

Burdyga, T., \& Kosterin, S. (1991). Kinetic analysis of smooth muscle relaxation. General Physiology and Biophysics, 10, 589-598.

Calixto, J., \& Medeiros, Y. (1992). Bradykinin-induced biphasic response in the rat isolated stomach fundus: Functional evidence for a novel bradykinin receptor. Life Sciences, 50(7), PL47-PL52.

Chan, S., \& Rudd, J. (2006). Role of bradykinin $\mathrm{B}_{2}$ receptors in the modulation of the peristaltic reflex of the guinea pig isolated ileum. European Journal of Pharmacology, 539, 108-115.

Choi, S., Park, D. Y., Yeum, C. H., Chang, I. Y., You, H. J., Park, C. G., Kim, M. Y., Kong, I. D., So, I., Kim, K. W., \& Jun, J. Y. (2006). Bradykinin modulates pacemaker currents through bradykinin $\mathrm{B}_{2}$ receptors in cultured interstitial cells of Cajal from the murine small intestine. British Journal of Pharmacology, 148(7), 918-926.

Dziadulewicz, E., Brown, M., Dunstan, A., Lee, W., Said, N., \& Garratt, P. (1999). The design of non-peptide human bradykinin $B_{2}$ receptor antagonists employing the benzodiazepine peptidomimetic scaffold. Bioorganic and Medicinal Chemistry Letters, 9(3), 463-468. 
Fattori, D., Rossi, C., Fincham, C. I., Caciagli, V., Catrambone, F., D’Andrea, P., Felicetti, P., Gensini, M., Marastoni, E., Nannicini, R., Paris, M., Terracciano, R., Bressan, A., Giuliani, S., Maggi, C. A., Meini, S., Valenti, C., \& Quartara, L. (2007). Design and synthesis of novel sulfonamidecontaining bradykinin $\mathrm{hB}_{2}$ receptor antagonists. 2. Synthesis and structureactivity relationships of alpha,alpha-cycloalkylglycine sulfonamides. Journal of Medicinal Chemistry, 50(3), 550-565.

Gierthmuhlen, J., Binder, A., \& Baron, R. (2014). Mechanism-based treatment in complex regional pain syndromes. Nature Reviews Neurology, 10(9), $518-528$.

Hall, J. (1997). Bradykinin receptors. General Pharmacology: The Vascular System, 28(1), 1-6.

Jaiswal, A., Kumar, S., Enjamoori, R., Seth, S., Dinda, A., \& Maulik, S. (2010). Peripheral benzodiazepine receptor ligand Ro5-4864 inhibits isoprenaline-induced cardiac hypertrophy in rats. European Journal of Pharmacology 644, 146-153.

Kam, Y., Ro, J., Kim, H., \& Choo, H. (2005). Antagonistic effects of novel non-peptide chlorobenzhydryl piperazine compounds on contractile response to bradykinin in the guinea-pig ileum. European Journal of Pharmacology, 523, 143-150.

Ludwig, J., \& Baron, R. (2004). Complex regional pain syndrome: An inflammatory pain condition? Drug Discovery Today: Disease Mechanisms, 4(1), 449-455.

Malasics, A., Boda, D., Valiskó, M., Henderson, D., \& Gillespie, D. (2010). Simulations of calcium channel block by trivalent cations: $\mathrm{Gd}^{3+}$ competes with permeant ions for the selectivity filter. Biochimica et Biophysica Acta - Biomembranes, 1798(11), 2013-2021.

Marcon, R., Claudino, R., Dutra, R., Bento, A., Schmidt, E., Bouzon, Z., Sordi, R., Morais, R., Pesquero, J., \& Calixto, J. (2013). Exacerbation of DSS-induced colitis in mice lacking kinin B1 receptors through compensatory up-regulation of kinin $\mathrm{B}_{2}$ receptors: The role of tight junctions and intestinal homeostasis. British Journal of Pharmacology, 168(2), 389-402.

Meini, S., Cucchi, P., Bellucci, F., Catalani, C., Giuliani, S., Santicioli, P., \& Maggi, C. (2007). Comparative antagonist pharmacology at the native mouse bradykinin $\mathrm{B}_{2}$ receptor: Radioligand binding and smooth muscle contractility studies. British Journal of Pharmacology, 150(3), 313-320.

Persona, K., Madej, K., Knihnicki, P., \& Piekoszewski, W. (2015). Analytical methodologies for the determination of benzodiazepines in biological samples. Journal of Pharmaceutical and Biomedical Analysis, 239(10), 239-264.

Prado, G., Taylor, L., Zhou, X., Ricupero, D., Mierke, D., \& Polgar, P. (2002). Mechanisms regulating the expression, self-maintenance, and signaling-function of the bradykinin $\mathrm{B}_{2}$ and $\mathrm{B}_{1}$ receptors. Journal of Cellular Physiology, 193, 275-286.

Reddy, D., Ballante, F., Zhou, N., \& Marshall, G. (2017). Design and synthesis of benzodiazepine analogs as isoform-selective human lysine deacetylase inhibitors. European Journal of Medicinal Chemistry, 127, 531-553.

Seidlmayer, L., Kuhn, J., Berbner, A., Arias-Loza, P. A., Williams, T., Kaspar, M., Czolbe, M., Kwong, J. Q., Molkentin, J. D., Heinze, K. G., Dedkova, E. N., \& Ritter, O. (2016). Inositol 1,4,5-trisphosphate-mediated sarcoplasmic reticulum-mitochondrial crosstalk influences adenosine triphosphate production via mitochondrial $\mathrm{Ca}^{2+}$ uptake through the mitochondrial ryanodine receptor in cardiac myocytes. Cardiovascular Research, 112(1), 491-501.

Stadnicki, A. (2011). Intestinal tissue kallikrein-kinin system in inflammatory Bowel disease. Inflammatory Bowel Diseases, 17(2), 645-654.

Virych, P., Sheljuk, O., Kabanova, T., Halimova, O., Martynjuk, V., Pavlovs'kyj, V., \& Andronati, S. (2017). Vplyv 2-arylamino-1,2-dygidro-3N-1,4benzdiazenip-2-ioniv na bradykinin-indukovane skorochennja gladen'kyh m'jaziv. Regulatory Mechanism in Biosystems, 8(1), 30-35 (in Ukrainian).

Virych, P., Shelyuk, O., Kabanova, T., Khalimova, E., Martynyuk, V., Pavlovsky, I., \& Andronati, S. (2017). Effect of 3-substituted 1,4-benzodiazepin-2-ones on bradykinin-induced smooth muscle contraction. Ukrainian Biochemical Journal, 89(1), 31-37.

Zhang, X., Brovkovych, V., Zhang, Y., Tan, F., \& Skidgel, R. (2015). Downregulation of kinin $B_{1}$ receptor function by $B_{2}$ receptor heterodimerization and signaling. Cell Signalling, 27(1), 90-103. 